\title{
A seasonal cycle in the export of bottom water from the Weddell Sea
}

\author{
Arnold L. Gordon*1 ${ }^{1}$, Bruce Huber ${ }^{1}$, Darren McKee ${ }^{1}$, Martin Visbeck ${ }^{2}$ \\ ${ }^{1}$ Lamont-Doherty Earth Observatory of Columbia University, Palisades, NY, \\ USA 10964 \\ ${ }^{2}$ Leibniz-Institut fuer Meereswissenschaften (IFM-GEOMAR) \\ Duesternbrooker Weg 20 D-24105 Kiel, Germany \\ *Corresponding Author: \\ Arnold L. Gordon \\ Lamont-Doherty Earth Observatory \\ 61 Route 9W \\ Palisades, NY 10964-8000 \\ tele: $01845365-8325$ \\ fax: $01845365-8157$ \\ agordon@ldeo.columbia.edu
}

B. Huber: bhuber@1deo.columbia.edu, 01845 365-8329

D. McKee: dcm2117@columbia.edu, 01845 365-8820

M. Visbeck: mvisbeck@ifm-geomar.de, +49-431-600-4100 
Dense water formed over the Antarctic continental shelf rapidly descends into the deep ocean to spread as Antarctic Bottom Water, ventilating the global ocean $^{1,2}$. The coldest and most voluminous component is Weddell Sea Bottom Water ${ }^{1,3,4,5,6,7}$. Here we present an 8-year observational record (3 April 1999 to 29 January 2007) of the benthic layer stratification within the Weddell Sea Bottom Water export path southeast of the South Orkney Islands. A pronounced bottom temperature seasonal cycle is apparent, with the coldest pulse in May/June, warmest in October/November, though the timing of these phases vary with year. The cold pulse thermohaline characteristics and mean bottom current of $0.1 \mathrm{~m} / \mathrm{s}$ indicate an origin in the southwest Weddell Sea, with shelf water discharge during the prior austral summer. The coldest bottom occurred in 1999 and 2002; in 2000 the cold phase was absent. We propose that the Weddell Sea Bottom Water seasonal fluctuation is governed by the wind seasonal cycle over the Weddell Sea western margin, with the interannual fluctuations linked to variability of the wind-driven Weddell Gyre. The observations suggest a link of Weddell Sea Bottom Water generation to the Southern Annular Mode and El Niño Southern Oscillation.

The ratio of Antarctic Bottom Water (AABW) to North Atlantic Deep Water (NADW) volume within the deep ocean is estimated as 1.7 , with AABW covering more than twice the sea floor area than $\mathrm{NADW}^{8}$. Observations within 
the Southern Ocean's Pacific sector indicate a decadal trend of decreasing salinity by increased glacial melt water ${ }^{9,10,11}$, which if continued might be expected to reduce the formation rate of bottom water. Trends in the Weddell Sea are less clear.

The cyclonic flowing Weddell Gyre is the dominant circulation feature south of the Antarctic Circumpolar Current in the Southern Ocean's Atlantic sector ${ }^{5}$. Relatively warm circumpolar deep water enters the Weddell Gyre east of the Greenwich Meridian, cooling as it traverses westward within the coastal current forming the gyre's poleward limb ${ }^{12}$. It eventually reaches the southwestern Weddell Sea and the eastern margins of Antarctic Peninsula, where it spreads onto the continental shelf. Sea-air-ice exchange over the shelf forms freezing point, dense, high salinity shelf water (HSSW). The export of the dense shelf water across the outer edge of the shelf ${ }^{13}$ leads to Weddell Sea Bottom Water $(\mathrm{WSBW})^{5,7,14,15}$.

Temperature/salinity (T/S) sensors and current meters moored southeast of the South Orkney Islands (Fig. 1) provide a timeseries within the axis of the eastward flowing WSBW stream, as identified by archived Weddell Sea data $^{5,14,16}$. We find a distinct seasonal cycle of bottom water characteristics at $\mathrm{M}_{3}$, interrupted by an anomalous warm period in 2000 (Fig. 2). The 6-year 1999-2005 record from $\mathrm{M}_{2}$ within the Weddell Sea Deep Water (WSDW), which is a mixture of WSBW and Weddell Warm Deep Water, ranging from $0.0^{\circ} \mathrm{C}$ to $-0.7^{\circ} \mathrm{C}^{14}$ shows 
the 2000 anomaly but does not display the distinct $\mathrm{M}_{3}$ seasonal cycle (Fig. 2), presumably because the bottom intensified injection of dense shelf water into the WSBW layer is attenuated during the mixing process leading to WSDW. At $\mathrm{M}_{3}$ the bottom potential temperature $\left(\theta^{\circ} \mathrm{C}\right)$ multi-year mean seasonal cycle ranges from $-0.85^{\circ} \mathrm{C}$ to $-0.96^{\circ} \mathrm{C}$, with the coldest pulse in May/June and the warmest in October/November. The monthly timeseries range is nearly $0.3^{\circ} \mathrm{C}$, with the daily $\theta^{\circ} \mathrm{C}$ fluctuations of $0.1^{\circ} \mathrm{C}$ from the monthly curve. The temperature difference between the bottom water and that $500 \mathrm{~m}$ off the sea floor increases as the bottom temperature decreases. Increased stratification coinciding with the coldest bottom water is an expected product as the shelf water injection is bottom intensfied ${ }^{2}$.

The monthly timeseries shows that the cold and warm pulses timing and amplitude vary markedly with year. The coldest events occurred in 1999 and 2002, while in 2000 it was absent. After 2002 the deviations from the mean seasonal cycle are small, with slight cooling from late 2003 into early 2005 . The bottom salinity also reveals interannual changes, with relatively salty bottom water observed in 2001 and 2002. The salinity variability forms a 'fan-like' appearance of the $\mathrm{M}_{3}$ WSBW $\theta / \mathrm{S}$ scatter (Fig. 3), suggesting a variable source of the shelf water end-member. The $\theta / \mathrm{S}$ characteristics indicate a Ronne Ice Shelf HSSW origin ${ }^{5}$, with the lower salinity WSBW derived from the shelf further north along the eastern margins of Antarctic Peninsula ${ }^{5,7,14,15}$. In consideration of the distance along the continental margin from likely sources of shelf water to the average timing of the $\mathrm{M}_{3}$ cold pulse peak of 1 June and using the approximate 
mean bottom speed of $\sim 0.1 \mathrm{~m} / \mathrm{s}$ at $\mathrm{M}_{3}$, the export of the shelf water is estimated to occur during the December / January time frame. Austral summer release of dense shelf water is observed in the Ross Sea ${ }^{17}$.

The $\mathrm{M}_{3} 1999$ cold bottom water event is followed by an abrupt increase of temperature and salinity in March 2000 (Fig. 2), which continued until March 2001. The "warm spell" accelerated in August 2000. We interpret the 2000-2001 warm event as the absence of shelf water export in the 1999/2000 austral summer. As the locally produced WSBW drained away from the mooring site the benthic layer was eventually replaced in August 2000 with the deep water from the southern limb of the Weddell Gyre, which is saltier than that of similar temperature water along the northern limb that normally incorporates newly formed WSBW. This is evident in comparison of the WOCE A23 ${ }^{18}$ stations 9-22 (southern limb) with 23-31 (northern limb; see Fig. 4c of ref 18). The normal seasonal curve returned in April 2001. The first half of 2002 was marked by anomalously cold bottom water at $\mathrm{M}_{3}$.

The export of shelf water depends on shelf water abundance and the release mechanism across the shelf break. As the residence time of the Weddell shelf water is of order 5 years ${ }^{19}$, at the yearly timescale the release mechanism is the primary factor, but at longer timescales, replenishment of the HSSW inventory becomes increasingly important. It is proposed that the seasonal variability of the shelf water export, and the anomalous 1999-2001 and 2002 interludes are related to the varying regional wind, which affects the shelf front 
position and the Weddell Gyre intensity. Before providing evidence in support of this hypothesis we caution: the Weddell timeseries at a fixed location within the Weddell Gyre northern limb may record variability in the path of a quasi-fixed WSBW stream or changes in the thermohaline composition of the WSBW stream. We advocate the latter: that the observed bottom water variability is a response to changes in shelf water discharge. This assertion is supported by the placement of the moorings near a steep topographic escarpment (Fig. 1) that provides boundary guiding of the WSBW stream. Additionally, the cold bottom water is strongly bottom intensified and has a seasonal signal distinct from that of the WSDW, attesting to its gravity current ${ }^{2}$ origin, which is expected to exhibit temporal fluctuations. Furthermore the mean bottom water gradients across the Weddell Gyre (Fig. 1; and bottom water maps ${ }^{16}$ ) cannot duplicate the observed thermohaline fluctuations recorded at $\mathrm{M}_{3}$ by simple gyre shifting.

Assuming the availability of dense shelf water, its export to the deep ocean depends on the position of the shelf/slope front relative to the outer edge of the shelf. Shoreward position of the front stymies shelf water escape. We proposed that the austral summer timing of the shelf water export is a consequence of the seasonal wind cycle (Fig. 4a). Strong winter wind towards the northeast induces large Ekman transport towards the northwest, pressing western Weddell Shelf break front shoreward restricting access of dense HSSW to the continental slope. In the austral summer this effect is reduced with the wind 
strength, allowing the intrinsic seaward pressure gradient associated with the dense shelf water to shift seaward, prompting escape to the slope.

Interannual variability of $\mathrm{M}_{3}$ bottom temperatures may be linked to prolonged periods of strong northward wind (Fig. 4b), which increase dense shelf water production by inducing a more active winter coastal polynya adjacent to the Ronne Ice Shelf ${ }^{20}$. Strong summer meridional winds act to remove freshwater locked up within advected sea ice floes, preconditioning the region for increased production of dense shelf water in the subsequent winter. A model study ${ }^{21}$ links the meridional wind, sea ice concentration, and HSSW. The strong northward winds in 1998 have been shown to have created an anomalous glut of $\mathrm{HSSW}^{20}$, which might have led to the 1999 cold anomaly. Similarly the prolonged strong northwards wind of 2000 and 2001 led to the $2002 \mathrm{M}_{3}$ cold event. Weak northward wind is not conducive to dense shelf water formation, therefore the period of weak or southward wind in 1999 did not 'refill' the shelf water inventory and reduced the potential for cold water export in the austral summer of 1999/2000, leading to anomalous warm bottom water in 2000 at $\mathrm{M}_{3}$. Additionally, the stronger northward wind of 2000 may have also restricted the export of shelf water.

Weddell Sea winds, which we suggest are key importance in driving the WSBW variability, can be related to large scale climate indices such as the Southern Annular Mode (SAM) and El Niño Southern Oscillation (ENSO). A 
positive SAM phase is associated with stronger westerlies and increased wind stress curl over the Weddell Sea ${ }^{22,23}$, as seen in 1998 and late 2001 (Fig. 4c) resulting in conditions favorable for increased export of WSBW by depressing the depth of the pycnocline over the continental slope, demonstrated by anomalously cold pulses in 1999 and 2002. Over longer time periods stronger westerlies engender greater injection of warm circumpolar deep water into the Weddell Gyre $^{4}$, which may eventually add salt to the shelf increasing production of bottom water ${ }^{24}$. However, in the peninsula region, low pressure anomaly causes weaker or southward winds in the western Weddell that may decrease HSSW formation ${ }^{20}$. This is seen in Fig. 4d after the prolonged positive SAM in $1998-2000$. On longer time scales surface layer freshening occurs during the positive SAM phase $^{25}$.

ENSO also affects the Weddell Sea (Fig. 4d). Cold (warm) events are characterized by anomalous low (high) pressure over the Bellingshausen Sea region, affecting the conditions on the Atlantic side of the peninsula and lesser on the Pacific side, causing a dipole pattern in ice edge extent, meridional winds, and surface air temperature ${ }^{26,27}$. The strong El Nino of $1997-1998$ relates to strong northward winds in the western Weddell Sea in 1998 while the strong La Nina that followed relates to the reversed offshore winds of 1999. Though weaker, the $2002-2003$ El Nino anomaly supports this as well.

The Weddell Sea wind field also reflects the overlapping effects of the 
SAM and $\mathrm{ENSO}^{28,29}$. For example, the largest magnitude WSBW anomalies in 1999, 2000, and 2002 are all preceded by opposite-phase instances of ENSO and SAM. Likewise, when the phase relationship is unfavorable, the two modes may "cancel" each other's impacts. This is evident in late 2003 in which both indices are positive, the offshore winds are strong, but the cyclonic wind stress curl is anomalously weak. Hence the cold pulse in 2004 is not as cold as that in 1999 or 2002.

We find that WSBW export displays strong seasonal cycle of bottom temperature, with the coldest phase in the May/June period, though significant year to year changes are evident. The likely source of the cold water is the release of southwest Weddell Sea shelf water during the prior austral summer. The coldest bottom occurred in 1999 and 2002, while in 2000 the cold phase was absent. We propose that the seasonal and interannual fluctuations of WSBW export reflects variability of wind forced shelf water escape into the deep ocean from the southwest Weddell Sea. Extended timeseries of the AABW outflow is required to investigate the Southern Ocean meridional overturning circulation response a warming climate scenario and associated trends in climate indices ${ }^{30}$.

\section{Methods}

Two oceanographic moorings $\left(\mathrm{M}_{2}\right.$ and $\left.\mathrm{M}_{3}\right)$ have been maintained on the continental slope south of the South Orkney Plateau since their initial deployment 
in 1999 (Fig. 1). The moorings have been recovered and redeployed at varying time intervals, determined primarily by research vessel availability (Fig. 2). Mooring maintenance was scheduled on a time-and-space-available basis on several national programs' vessels: US Antarctic Program L M GOULD (LMG, 1999, 2000, 2003, 2004 and 2005) and NP PALMER (NBP, December 2001, 2006); Brazilian Antarctic Program NApOc ARY RONGEL (February 2001); and the British Antarctic Survey RRS ERNEST SHACKLETON (2007). Due to sea ice and weather constraints, mooring maintenance was not possible during the LMG 2003, 2004 and NBP 2006 cruises.

The moorings are anchored to the sea floor, each instrumented with 2 current meters (Aanderaa RCM8; 2000-2007), 2 conductivity-temperature recorders (SBE37 Microcat, $\mathrm{CT})$ and 3 temperature recorders (SBE39, T). $\mathrm{M}_{2}$ and $\mathrm{M}_{3}$ are similarly configured. The near-bottom current meter is nominally 15 $\mathrm{m}$ above the bottom. One of the CT recorders is positioned 5 to $25 \mathrm{~m}$ above the bottom current meter. The second current meter is positioned at the top of the mooring, nominally $500 \mathrm{~m}$ above the bottom, with the remaining CT instrument $50 \mathrm{~m}$ below that, $\sim 450 \mathrm{~m}$ off the bottom. The top two instruments are equipped with pressure sensors. The 3 temperature recorders are distributed on the intervening mooring line at approximately $125 \mathrm{~m}$ intervals.

The current meters sampled every 30 minutes; the CT every 15, and the T 7.5 minutes. The raw data were screened to remove deployment/recovery 
transients, then averaged and interpolated to a common hourly time base. Conductivity-Temperature-Depth (CTD) profiles were obtained near each of the mooring sites during the initial deployment and most of the subsequent maintenance cruises. A Sea-Bird Electronics (SBE) model 911 CTD was used in all cases, though with various sensor configurations which were calibrated by SBE before and after the cruises. Temperature-salinity characteristics from these CTD profiles were used to adjust the CT-derived salinities. Any temporal drift detected in the CT-CTD comparisons was applied to the CT-derived salinity by linear interpolation in time. The corrections applied to individual CT instruments as offsets ranged (in salinity) from 0.000 to 0.054 . The maximum temporal drift correction applied was 0.005 for the M2 deployment of Feb-Dec 2001, bottommost $\mathrm{CT}$ recorder. No corrections were applied to the $\mathrm{T}$ recorders, nor to the temperature data of the $\mathrm{CT}$ recorders.

For instruments with no intrinsic pressure sensors, pressure was inferred by interpolation from the nearest instrument with a pressure sensor, and the instrument's known relative position on the mooring wire. The shape of the mooring was assumed to be linear during vertical excursions of the instruments. Potential temperatures are computed for all temperature records, including those with no accompanying salinity, using either the intrinsic pressure record or the inferred pressure as described above. For temperature records with no corresponding measured salinity, we used a salinity derived from the average nearby CTD profiles at the nominal depth of the instrument. For the observed 
range in deep salinities of 0.010 , we estimate the corresponding error in potential temperature to be less than $0.001{ }^{\circ} \mathrm{C}$.

Data sources for Fig. 4: the IRI/LDEO Climate Data Library provided the data for panels a-c and for the Nino3.4 index in $\mathbf{~ d ~ ( h t t p : / / i r i d l . l d e o . c o l u m b i a . e d u / ) . ~}$ The SAM index in $\mathbf{d}$ is the British Antarctic Survey's “observation-based Southern Hemisphere Annular Mode Index“ ( http://www.antarctica.ac.uk/met/gjma/sam.html ). The dashed curves in $\mathbf{b}$ and $\mathbf{c}$ are 12-month running means of the corresponding solid curves. The indices in $\mathbf{d}$ have been smoothed with a 6 month Butterworth filter.

\section{$\underline{\text { Data gaps }}$}

The time series in Figure 2a display several gaps in the records, described below. Speed: Current meters deployed in 1999-2000 (OEI VACM) yielded no data. The deployment of late 2001 through early 2005 exceeded the battery capacity of the RCM8 current meters, so the $\mathrm{M}_{3}$ bottom speed record ends prematurely in January 2004.

Salinity: Bottom salinity at $\mathrm{M}_{3}$ was truncated in early 2004 owing to a failed conductivity sensor. The $\mathrm{M}_{3}$ salinity record from $450 \mathrm{~m}$ above bottom for the 2005-2007 deployment was edited to remove bad conductivity values at the beginning of the record, presumably due to foreign matter occluding or entering the conductivity cell during deployment and later flushed out. The $\mathrm{M}_{2}$ salinity record (dashed blue line) was truncated in mid-2003 due to a failed pressure sensor, which rendered the conductivity values unreliable. 
Temperature: The bottom CT recorder in 2001-2005 from which the temperature record is derived filled its memory before the end of the deployment. As noted above, the conductivity cell failed before this, so the calculation of potential temperature for the remaining record was performed as described above. Battery capacity was exceeded for the 2001-2005 records at 150 and $350 \mathrm{~m}$ (magenta and red traces).

\section{References:}

1. Orsi, A. H., Johnson, G. C. \& Bullister, J. L. Circulation, mixing, and production of Antarctic Bottom Water, Prog. Oceanogr., 43, 55-109 (1999).

2. Legg, S., and co-authors, Improving oceanic overflow representation in climate models: the Gravity Current Entrainment Climate Process Team, Bulletin of the American Meteorological Society, 90, 657-670 (2009).

3. Carmack, E. C. \& Foster, T. D. On the flow of water out of the Weddell Sea, Deep Sea Res., 22, 711-724 (1975).

4. Fahrbach, E., Rohardt, G., Schröder, M. \& Strass, V. Transport and structure of the Weddell Gyre, Ann. Geophys., 12, 840-855 (1994).

5. Gordon, A. L. Western Weddell Sea thermohaline stratification, in Ocean, Ice, and Atmosphere: Interactions at the Antarctic Continental Margin, Antarct. Res. Ser., 75, edited by S. S. Jacobs and R. F. Weiss, pp. 215-240, AGU, Washington, D. C. (1998). 
6. Meredith, M., Locarnini, R., Van Scoy, K., Watson, A., Heywood, K. \& King, B. On the sources of Weddell Gyre Antarctic Bottom Water, J. Geophys. Res., 105, 1093-1104 (2000).

7. Nicholls, K. W., Østerhus, S., Makinson, K., Gammelsrød, T. \& Fahrbach, E. Ice-ocean processes over the continental shelf of the southern Weddell Sea, Antarctica: A review, Rev. Geophys., 47, RG3003, doi:10.1029/2007RG000250, (2009).

8. Johnson, G. C.. Quantifying Antarctic Bottom Water and North Atlantic Deep Water volumes. J. Geophys. Res., 113, C05027, doi:10.1029/2007JC004477 (2008).

9. Jacobs, S. S., Giulivi, C. F. \& Mele, P. Freshening of the Ross Sea during the late 20th century, Science, 297, 386- 389 (2002).

10. Rintoul, S. R. Rapid freshening of Antarctic Bottom Water formed in the Indian and Pacific oceans, Geophys. Res. Lett., 34, L06606, doi:10.1029/2006GL028550 (2007).

11. Jacobs, S.S. \& Giulivi, C. F.. Large Multi-decadal Salinity Trends near the Pacific-Antarctic Continental Margin. J. Climate (in press) 2010.

12. Hellmer, H. H., Kauker, F. \& Timmermann, R. Weddell Sea anomalies: Excitation, propagation, and possible consequences, Geophys. Res. Lett., 36, L12605, doi:10.1029/2009GL038407 (2009).

13. Foster, T. D., Foldvik, A. \& Middleton, J. H. Mixing and bottom water formation in the shelf break region of the southern Weddell Sea, Deep Sea Res., 
34, 1771 - 1794, doi:10.1016/0198-0149(87)90053-7 (1987).

14. Gordon, A.L., Visbeck, M. \& Huber, B. Export of Weddell Sea Deep and Bottom Water. J. Geophys. Res., 106, $9005-9017$ (2001).

15. Huhn, O., Hellmer, H. H., Rhien, M., Rodehacke, C., Roether, W., Schodlok, M. \& Schroder, M. Evidence of Deep and bottom water formation in the western Weddell Sea. Deep-Sea Res. II 55, 1098-1116 (2008).

16. Orsi, A. H., \& Whitworth III, T. Hydrographic Atlas of the World Ocean Circulation Experiment (WOCE), vol. 1, Southern Ocean, edited by M. Sparrow, P. Chapman, and J. Gould, Int. World Ocean Circ. Exp. Proj. Off., Southampton, U. K. (2005).

17. Gordon, A.L., Orsi, A. H., Muench, R., Huber, B. A., Zambianchi, E. \& Visbeck, M. Western Ross Sea Continental Slope Gravity Currents. Deep-Sea Research Part II, “Southern Ocean Shelf Slope Exchange”, 56, 796-817. Editors:

A. Gordon, L. Padman, A. Bergamasco, doi:10.1016/j.dsr2.2008.10.037 (2009).

18. Heywood, K.J. \& King, B.A., Water masses and baroclinic transports in the South Atlantic and Southern Oceans. J. Marine Research, 60, 639-676 (2002).

19. Mensch M, Bayer, R., Bullister, J., Schlosser, P. \& Weiss, R., The distribution of tritium and CFCs in the Weddell Sea during the mid-1980s, Progress in Oceanography, 38, 377-415 (1996).

20. Ackley, S.F., Geiger, C.A., King, J.C., Hunke, E.C. \& Comiso, J. The Ronne Polynya of 1997/98: observations of air-ice-ocean interaction, Ann. of Glac., 33, $425-429(2001)$ 
21. Timmermann, R., Hellmer, H. H. \& Beckmann, A. Simulations of ice-ocean dynamics in the Weddell Sea 2, Interannual variability 1985 - 1993. J. Geophys. Res., 107, doi:10.1029/2000JC000742, (2002).

22. Lefebvre, W., Goosse, H., Timmermann, R., \& Fichefet, T. Influence of the Southern Annular Mode on the sea ice-ocean system, J. Geophys. Res., 109, C09005, doi:10.1029/2004JC002403 (2004).

23. Visbeck, M., A Station-Based Southern Annular Mode Index from 1884 to 2005. J. Climate, 22, 940-95 (2009).

24. Hall, A. \& Visbeck, M. Synchronous variability in the Southern Hemisphere, sea ice, and ocean resulting from the annular mode. J. Climate, 15, 3043-3057 (2002).

25. Gordon, A.L., Visbeck, M. \& Comiso, J.C. A possible link between the Weddell Polynya and the Southern Annular Mode. J. Climate, 20, 2558-2571 (2007).

26. Yuan, X. ENSO-related impacts on Antarctic sea ice: a synthesis of phenomenon and mechanisms, Antarctic Science, 16, 415-425, DOI:10.1017/S0954102004002238 (2004).

27. Yuan, X. \& Martinson, D.G. Antarctic sea-ice extent variability and its global connectivity, J. Climate, 13, 1697-1717 (2000).

28. Simmonds, I. \& King, J.C.. Global and hemispheric climate variations affecting the Southern Ocean. Antarctic Science, 16, 401-413 (2004).

29. Stammerjohn, S.E., Martinson, D.G., Smith, R.C., Yuan, X. \& Rind, D. 
Trends in Antarctic annual sea ice retreat and advance and their relation to El Nino-Southern Oscillation and Southern Annular Mode variability. J. Geophys. Res., 108, C03S90, doi:10.1029/2007JC004269 (2008).

30. Rintoul, S. \& Co-Authors, Southern Ocean Observing System: Rationale and Strategy for Sustained Observations of the Southern Ocean. in Proceedings of OceanObs'09: Sustained Ocean Observations and Information for Society (Vol. 2), Venice, Italy, 21-25 September 2009, Hall, J., Harrison D.E. \& Stammer, D., Eds., ESA Publication WPP-306 (2010).

\section{Acknowledgments}

This research was funded under the Cooperative Institute for Climate Applications Research (CICAR) award number NA08OAR4320754 from the National Oceanic and Atmospheric Administration, U.S. Department of Commerce. The statements, findings, conclusions, and recommendations are those of the author(s) and do not necessarily reflect the views of the National Oceanic and Atmospheric Administration or the Department of Commerce. Lamont Doherty Contribution number xxxx.

\section{Author contributions}

ALG, led the data analysis and leads the data collection program. BAH, supervised the collection and processing the data reported, and prepared the Methods section. DM investigated the relation of the Weddell Sea wind. MV 
contributed to the SAMS discussion and was instrumental in the initiation of the Weddell timeseries.

\section{Additional Information}

Data are archived and made available as they are recovered from the moorings at the project web site:

http://www.ldeo.columbia.edu/res/div/ocp/projects/corc.shtml

The authors declare no competing financial interests.

\section{Figures Captions}

Figure 1. Weddell Sea moorings. a, The Weddell Sea; b, location of moorings $\mathrm{M}_{2}$ and $\mathrm{M}_{3}$. The bottom depth and mooring location are: $\mathrm{M}_{2}: 3096 \mathrm{~m}, 62^{\circ} 38^{\prime} \mathrm{S}$; $43^{\circ} 15^{\prime} \mathrm{W} ; \mathrm{M}_{3}: 4560 \mathrm{~m}, 63^{\circ} 32^{\prime} \mathrm{S} ; 4^{\circ} 47^{\prime} \mathrm{W}$. The record length mean bottom current $(\mathrm{cm} / \mathrm{s})$ is shown in vector form at $\mathrm{M}_{2}$ and $\mathrm{M}_{3}$. $\mathbf{c}$, potential temperature $\left(\theta^{\circ} \mathrm{C}\right)$ and $\mathbf{d}$, salinity $(\mathrm{S})$ The section along the line shown in $\mathbf{b}$ passing by each

mooring, obtained in $1997^{14}$ shows the mooring setting relative to the regional thermohaline stratification. The solid and dashed red lines are referred to in Fig. 4.

Figure 2. 8-year time series at mooring $\mathbf{M}_{2}$ and $\mathbf{M}_{3}$. 30 -day running mean $\theta^{\circ} \mathrm{C}$, salinity and bottom speed at $\mathrm{M}_{2}$ and $\mathrm{M}_{3}(\mathbf{a}) \cdot \mathrm{M}_{3} \theta^{\circ} \mathrm{C}$ and salinity are color coded by distance from the sea floor as shown in the insert in a. $\mathrm{M}_{2} \theta^{\circ} \mathrm{C}$ and salinity timeseries $15 \mathrm{~m}$ above the sea floor, are shown as a dashed blue line. The vertical dashed gray lines denote mooring recovery/re-deployment. $\mathbf{b}$, the $\mathrm{M}_{3}$ bottom $\theta^{\circ} \mathrm{C}$ daily (gray line), monthly (blue line) and the mean seasonal cycle (red line). The 
2004 gap in $\mathrm{M}_{3}$ bottom $\theta^{\circ} \mathrm{C}$ is filled with data from the instrument at $4447 \mathrm{~m}$, offset by the mean $\theta^{\circ} \mathrm{C}$ difference between it and the bottom record $\left(-0.027^{\circ} \mathrm{C}\right)$.

Figure 3. Bottom $\theta^{\circ} \mathbf{C}$ and salinity relationship at $\mathbf{M}_{2}$ and $\mathbf{M}_{3}$. a, Bottom water Ө/S scatter color-coded for bottom speed. The yellow dots are from the 1997 section shown in Fig. 1. The $\theta / \mathrm{S}$ location of the cold phases of the seasonal cycle for each year are identified.

Figure 4. Weddell Sea wind and climate indices. a, zonal (u) and meridional (v) wind $(\mathrm{m} / \mathrm{s})$, within the area $67^{\circ} \mathrm{S}$ to $76^{\circ} \mathrm{S} ; 45^{\circ} \mathrm{W}-62^{\circ} \mathrm{W}$, from NCEP-DOE Reanalysis 1996-2008 Climatology. b, Timeseries of spatially averaged v, within the solid red line in Fig. 1a. The blue arrows mark times of anomalous cold bottom water at $\mathrm{M}_{3}$; red arrows mark the anomalously warm bottom water events. The blue lines denote sustained strong northward winds; the red lines denote meridional wind of near zero or reversals. c, wind stress curl anomaly within the dashed red line indicated in Fig. 1a. The blue and red arrows as the same as shown in $\mathbf{b}$. The red lines denote periods of reduced wind stress curl (less cyclonic) by inference diminished Weddell Gyre; the blue lines are periods of increased cyclonic wind stress curl and gyre intensity. d, the SAM index (scale at left); $\mathrm{M}_{3}$ bottom $\theta^{\circ} \mathrm{C}$ anomaly (scale at right) and NINO3.4 index. The temperature variability in NINO3.4 is scaled to fit on the temperature axis. 

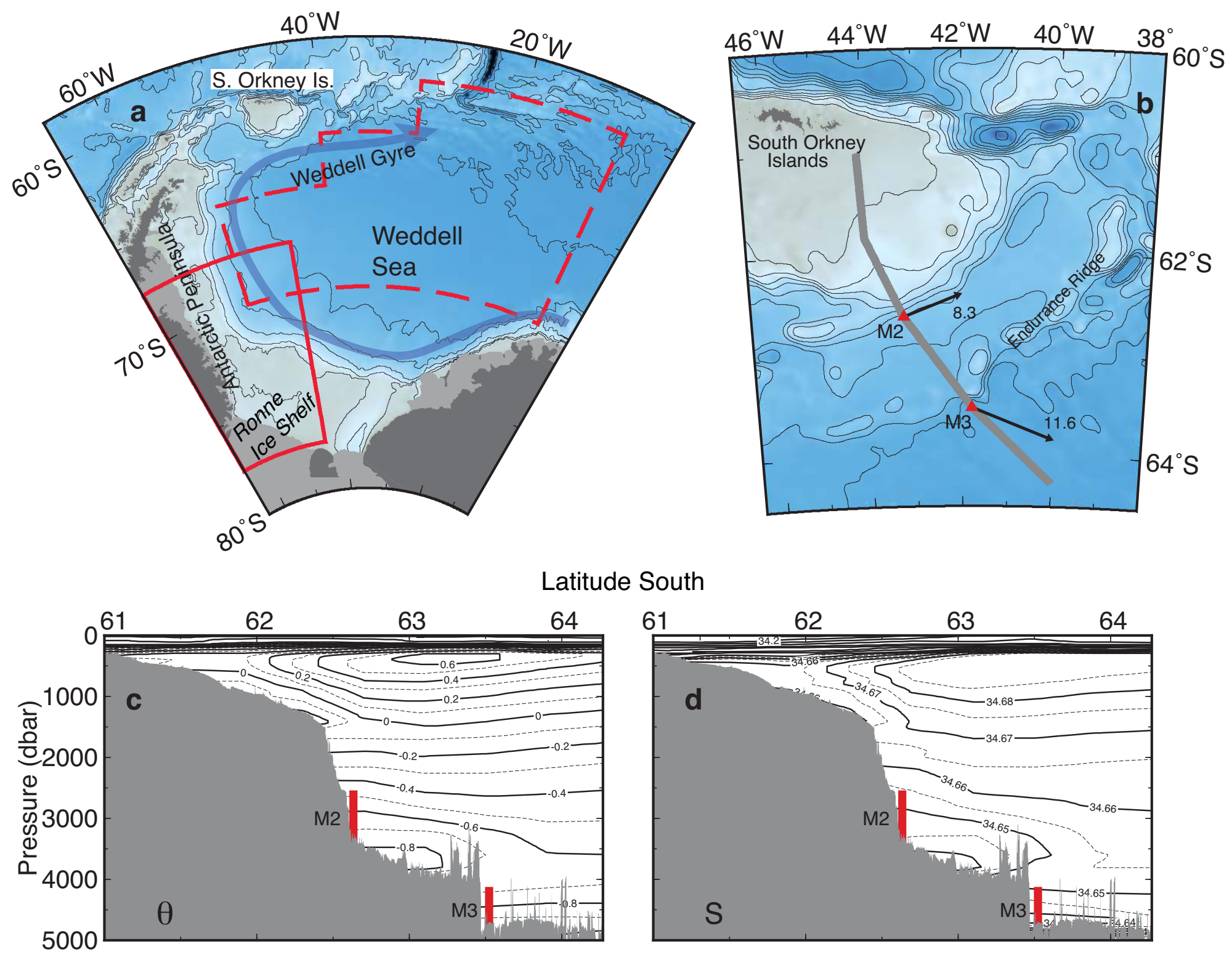

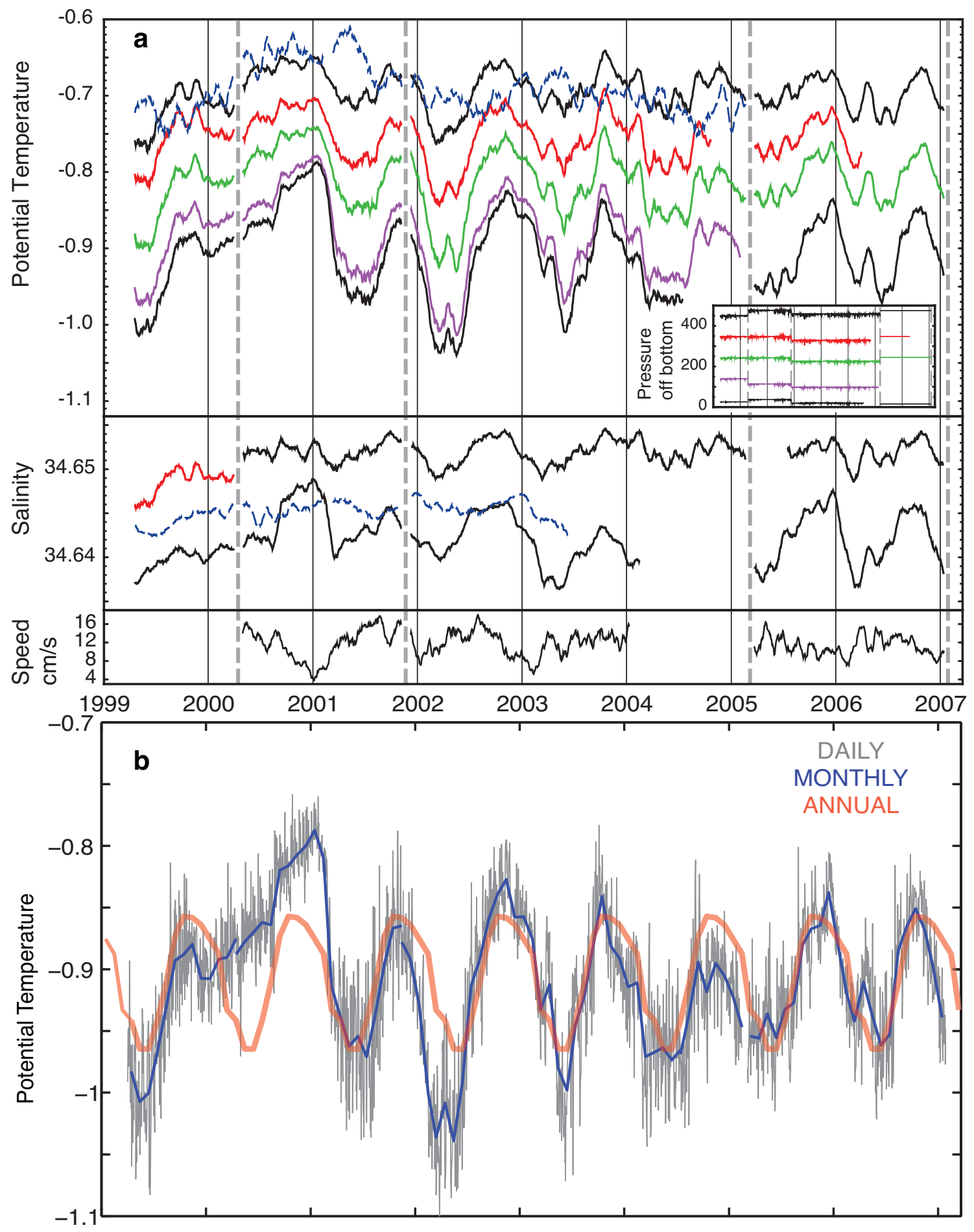


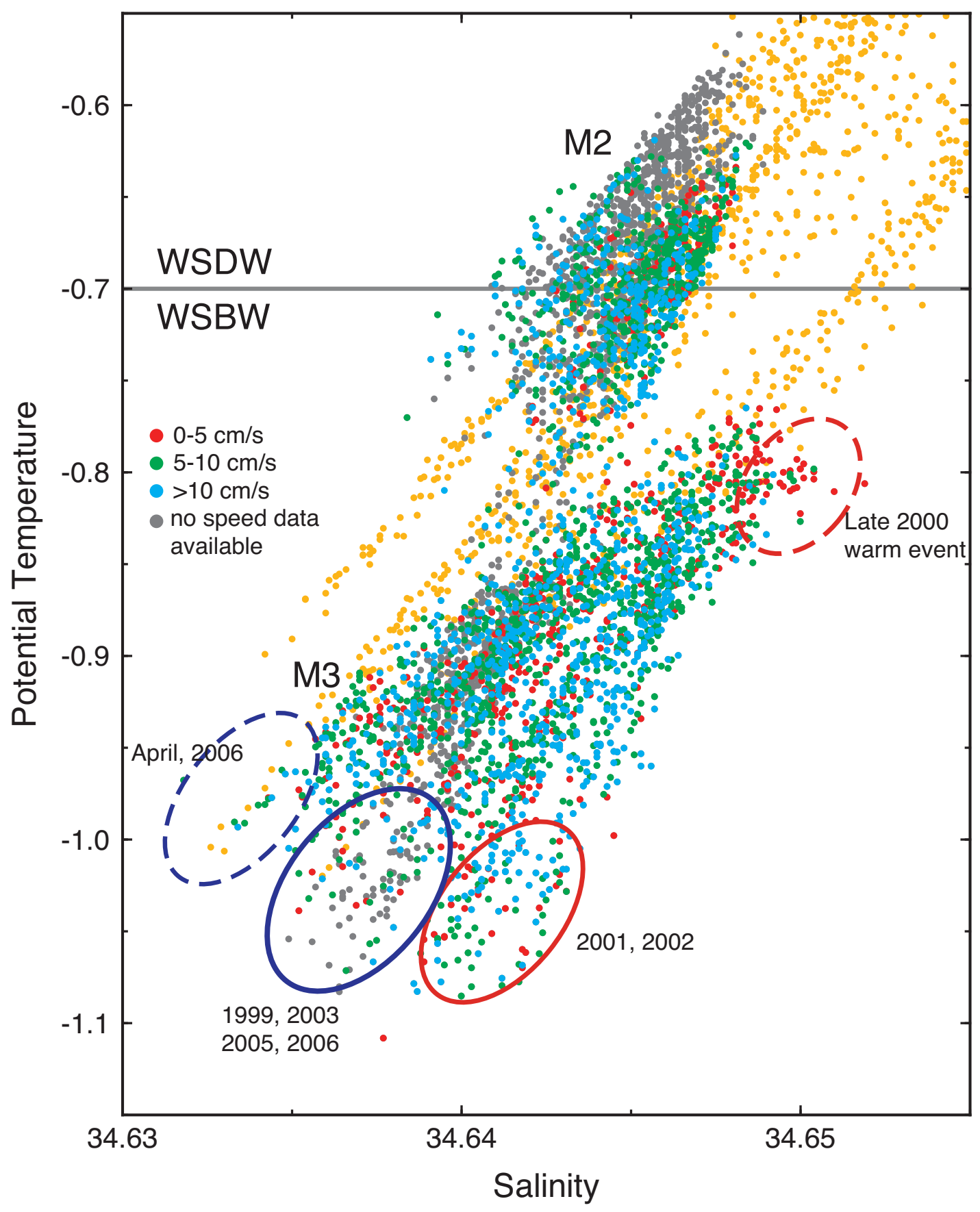



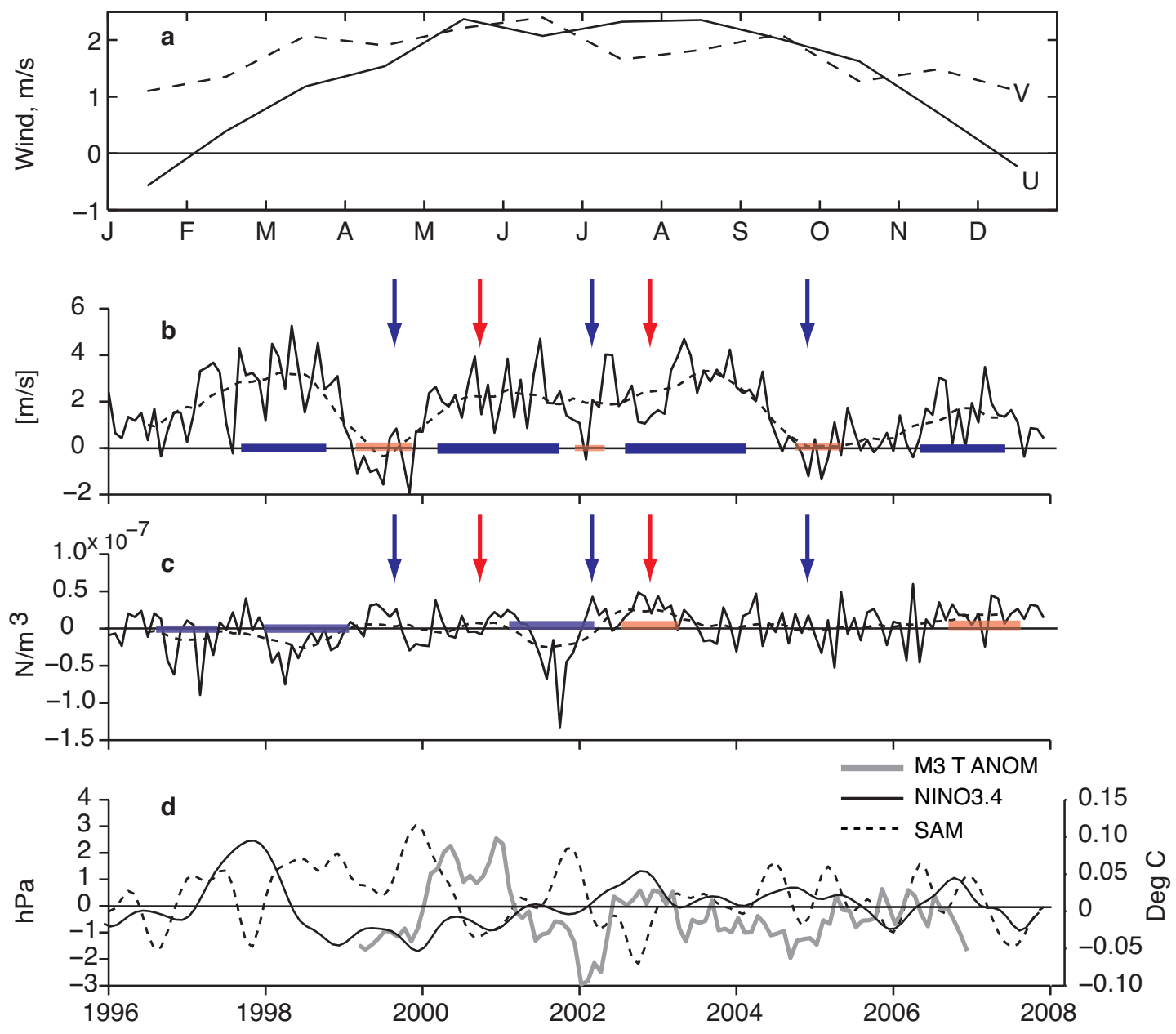